\title{
Correction to: A full sequence of the Matuyama-Brunhes geomagnetic reversal in the Chiba composite section, Central Japan
}

Yuki Haneda ${ }^{1,2,3^{*}}$, Makoto Okada ${ }^{2}$, Yusuke Suganuma ${ }^{1,4}$ and Takahiro Kitamura ${ }^{2}$

\section{Correction to: Prog Earth Planet Sci 7, 44 (2020) \\ https://doi.org/10.1186/s40645-020-00354-y}

Following publication of the original article by Haneda et al. (2020a), several values of authigenic ${ }^{10} \mathrm{Be} /{ }^{9} \mathrm{Be}$ in Fig. $7 \mathrm{i}$ and Additional file 2, and color of 6 plots around $12 \mathrm{~m}$ level in Fig. 7e were found to be incorrect. The corrected Fig. 7 and its caption is given below, and the corrected Additional file 2 is included in this correction. The original paper has been updated.

The original article can be found online at https://doi.org/10.1186/s40645020-00354-y

* Correspondence: yuuki.haneda.paleo@gmail.com

${ }^{1}$ National Institute of Polar Research, 10-3 Midori-cho, Tachikawa, Tokyo

190-8518, Japan

${ }^{2}$ Department of Earth Sciences, Ibaraki University, 2-2-1 Bunkyo, Mito, Ibaraki

310-8512, Japan

Full list of author information is available at the end of the article

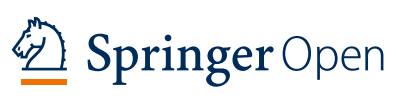

(-) The Author(s). 2021 Open Access This article is licensed under a Creative Commons Attribution 4.0 International License, which permits use, sharing, adaptation, distribution and reproduction in any medium or format, as long as you give appropriate credit to the original author(s) and the source, provide a link to the Creative Commons licence, and indicate if changes were made. The images or other third party material in this article are included in the article's Creative Commons licence, unless indicated otherwise in a credit line to the material. If material is not included in the article's Creative Commons licence and your intended use is not permitted by statutory regulation or exceeds the permitted use, you will need to obtain permission directly from the copyright holder. To view a copy of this licence, visit http://creativecommons.org/licenses/by/4.0/. 


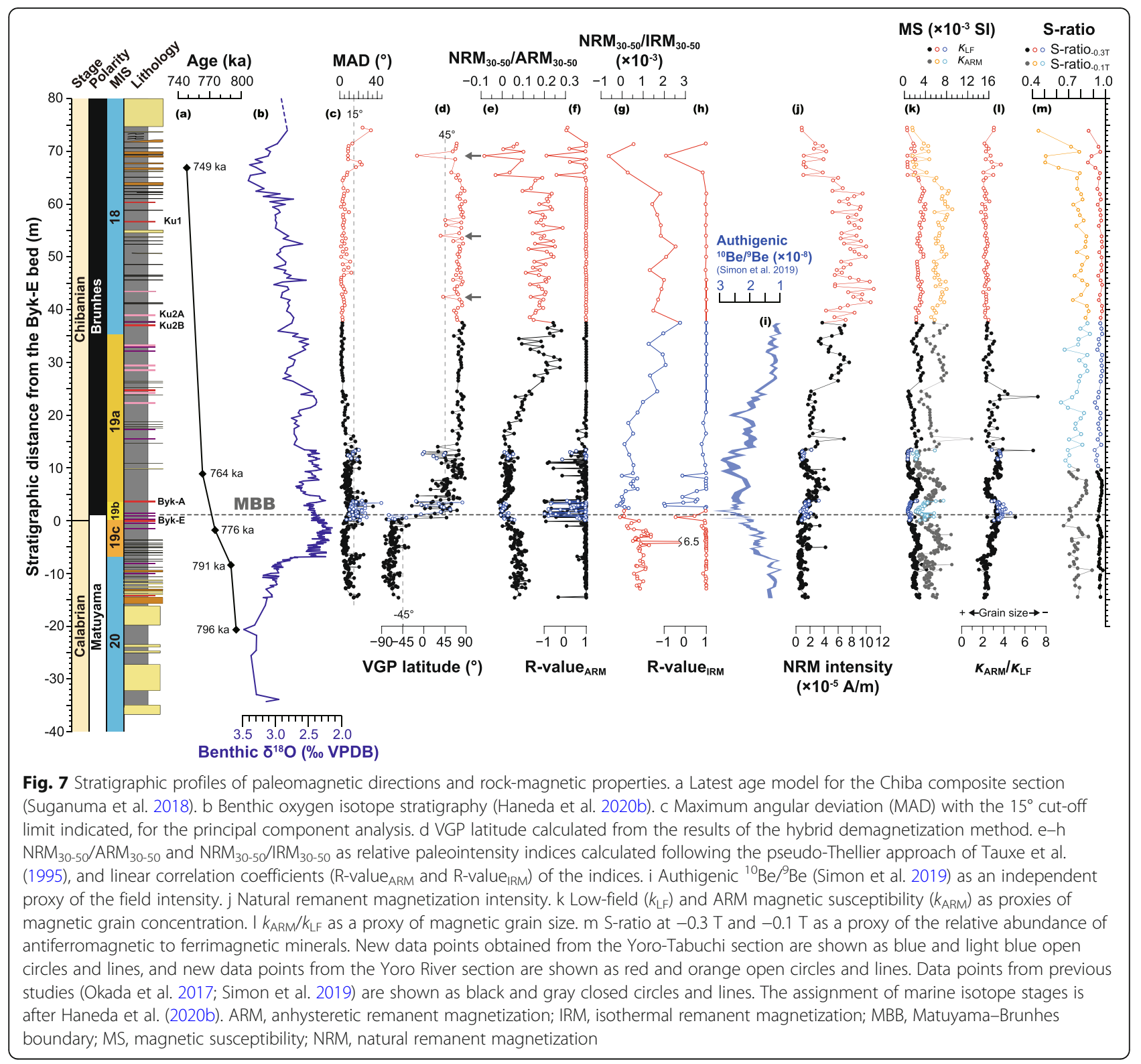

\section{Supplementary Information}

The online version contains supplementary material available at https://doi. org/10.1186/s40645-021-00423-w.

Additional file 2. Paleomagnetic and rock magnetic results for the Yoro River and Yoro-Tabuchi sections by Okada et al. (2017), Simon et al. (2019), and this study

\section{Author details}

'National Institute of Polar Research, 10-3 Midori-cho, Tachikawa, Tokyo 190-8518, Japan. ${ }^{2}$ Department of Earth Sciences, Ibaraki University, 2-2-1 Bunkyo, Mito, Ibaraki 310-8512, Japan. ${ }^{3}$ Present Address: Geological Survey of Japan, AIST, 1-1-1 Central 7, Higashi, Tsukuba, Ibaraki 305-8567, Japan. ${ }^{4}$ Department of Polar Science, School of Multidisciplinary Sciences, The Graduate University for Advanced Studies, SOKENDAl, Midori-cho 10-3, Tachikawa, Tokyo 190-8518, Japan.
Published online: 24 May 2021

\section{References}

Haneda $Y$ et al (2020a) A full sequence of the Matuyama-Brunhes geomagnetic reversal in the Chiba composite section, Central Japan. Prog Earth Planet Sci 7:44 https://doi.org/10.1186/s40645-020-00354-y

Haneda et al (2020b) Millennial-scale hydrographic changes in the northwestern Pacific during marine isotope stage 19: teleconnection with ice melt in the North Atlantic. Earth Planet Sci Let 531:115936 https://doi.org/10.1016/j.epsl.2 019.115936

Okada et al (2017) Paleomagnetic direction and paleointensity variations during the Matuyama-Brunhes polarity transition from a marine succession in the Chiba composite section of the Boso Peninsula, central Japan. Earth Planets Space 69:45 https://doi.org/10.1186/s40623-017-0627-1

Simon et al (2019) High-resolution ${ }^{10} \mathrm{Be}$ and paleomagnetic recording of the last polarity reversal in the Chiba composite section: Age and dynamics of the 
Matuyama-Brunhes transition. Earth Planet Sci Lett 519:92-100 https://doi. org/10.1016/j.epsl.2019.05.004

Suganuma et al (2018) Paleoclimatic and Paleoceanographic records of Marine Isotope Stage 19 at the Chiba composite section, central Japan: A reference for the Early-Middle Pleisotocene boundary. Quat Sci Rev 191:406-430 https://doi.org/10.1016/j.quascirev.2018.04.022

Tauxe et al (1995) Relative paleointensity in sediments: a Pseudo-Thellier approach. Geophys Res Lett 22:2885-2888 https://doi.org/10.1029/95GL0 3166 